\title{
Synthesis of New Conducting Polymers and Its Properties
}

\author{
新規導電性高分子の合成とその物性
}

\author{
Kazuhiko TANBO, Masanori SUGA , Seiichi SAITO , Atsumi KINOSHITA \\ Department of Applied Chemistry , Tokai University \\ 1117 Kitakaname, Hiratsuka , Kanagawa , 259-12 JAPAN \\ TEL:0463-58-1211 ex. 4174 \\ (Received 14, January 1994 Accepted 23, May 1994)
}

\begin{abstract}
Pyrrole derivatives which were substituted in the 3-position by an acyl and an alkyl, the 3,4-position by an alkyl ring were synthesized (compounds with a two, six and ten carbons normal chain and a six carbons ring). Their conductivity and solubility were investigated. Electrooxidation in acetonitril/lithiumtetrafluoroborate led to the deposition of brittle black conducting polymer films on the anode. The conductivity decreased with substitution of free positions. These conducting polymers had not solubility.
\end{abstract}

Keywords : new conducting polymers, substituted pyrrole, electrooxidation

\section{$1 \cdot$ 緒言}

導電性高分子の加工性は、工業材料として使用 する上で最も重要な条件の一つとなっている。剛 直な共役系二重結合からなる導電性高分子は、本 質的には不溶不融である。この欠点を改良し成形 加工性を付与する手段として、分子に適当な側鎖 をつけて有機溶媒や水に可溶化させる方法が、可 溶性導電性高分子の研究の中心となっている。1.2 そこで本研究では、ピロールを原料として、3 位または3,4位置換体を合成し、電解重合法に於 ける最適条件の設定および置換基による重合体の 溶解性、導電性について検討した。

\section{$2 \cdot$ 実験方法}

2.1 試 薬

1)N-トシルピロールの合成<smiles>[3H-]n1cccc1Cc1ccc[nH]1</smiles>

THF $100 \mathrm{ml} ヒ ゚ ロ ー ル 0.15 \mathrm{~mol}$ とカリウム $0.12 \mathrm{~mol}$ を加熱攪拌した。THF $100 \mathrm{ml}$ を加え希釈 し、P-トルエンスルホニルクロライド $0.10 \mathrm{~mol}$ THF $100 \mathrm{ml}$ に溶解させたものを滴下し、さらに18 時間攪拌した。塩を除き脱水後濃縮し、真空乾燥 した。生成物をメタノールで再結晶を行った。
2)3-アルキノイル・N-トシルピロールの合成

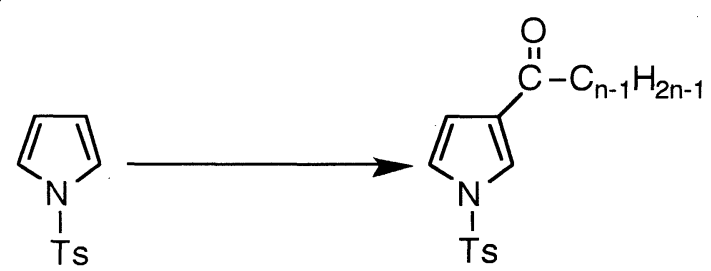

ジクロロメタン $80 \mathrm{ml}$ に塩化アルミニウム $0.0452 \mathrm{~mol}$ 攪拌し、室温でアシルクロライド

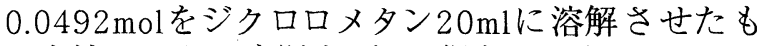
のを滴下した。内温を $5{ }^{\circ} \mathrm{C} に$ 保ちながら $\mathrm{N}$ トシシルピ ロール0.0492molをジクロロメタン $20 \mathrm{ml}$ に溶解させ たものを滴下した。1時間以上攪拌した後、室温 で12時間攪拌した。加水分解後、エーテル抽出し 有機層を分離し脱水し濃縮した。

3)3-アルカノイルピロールの合成

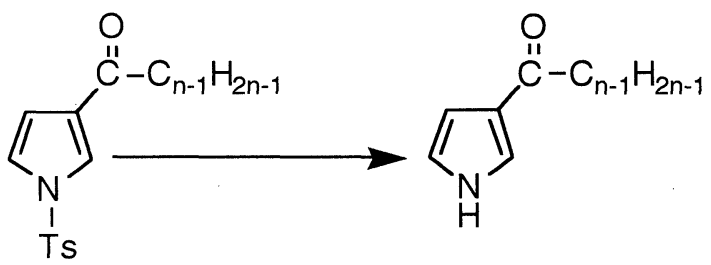

1,4-ジオキサン $120 \mathrm{ml}$ に3-アルカノイル-N-トシルピ ロール $0.020 \mathrm{~mol}$ と水酸化ナトリウム $0.100 \mathrm{~mol}$ を蒸 留水 $60 \mathrm{ml}$ に溶解させ 24 時間攪拌還流した。エーテ ル抽出し有機層を分離し脱水し濃縮した。 
4)3-アルキルピロールの合成

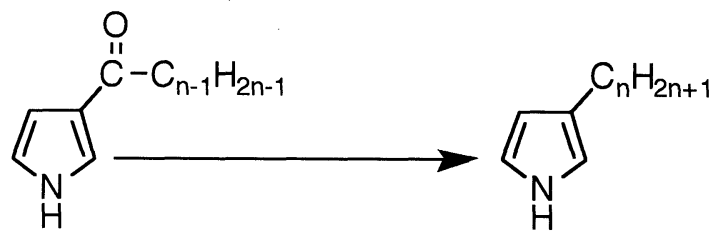

THF $100 \mathrm{ml}$ に水素化ビス(2-メトキシエトキシ)アル ミニウムナトリウム $0.025 \mathrm{~mol}$ 水冷下攪拌し 3 -アル カノイルピロール $0.0125 \mathrm{~mol}$ THF $100 \mathrm{ml}$ に溶解さ せたものを少しずつ加えた。室温で24時間、50 ${ }^{\circ} \mathrm{C}$ で 1 時間攪拌し、室温まで放冷した。加水分解 後、エーテル抽出し有機層を分離し脱水し濃縮し た。精製はカラムにより行った。

5)N-(P-トシルメチル)-ホルムアミドの合成

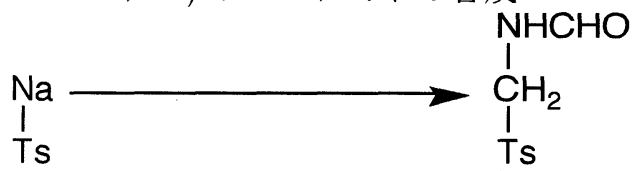

蒸留水 $250 \mathrm{ml}$ にP-トルエンスルフィン酸ナトリウ ム5水和物 $0.5 \mathrm{~mol}$ とホルムアルデヒド $1.47 \mathrm{~mol}$ とホル ムアミド $5.0 \mathrm{~mol}$ と蟻酸 $1.77 \mathrm{~mol} 90^{\circ} \mathrm{C}$ で 2 時間攪拌 した。水水で室温にし $-20^{\circ} \mathrm{C}$ で 24 時間放置した。 得られた結晶をろ過し、冷水洗浄し、ジクロロメ 夕ンに溶解し、有機層を分離し脱水し濃縮した。 6)P・トシルメチルイソシアニドの合成

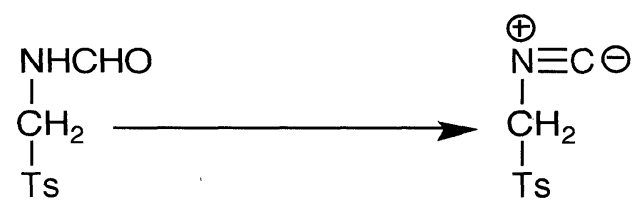

1,2-ジメトキシエタン $83.3 \mathrm{ml}$ ・無水エーテル 33.3mlにN-(P-トリルスルホニルメチルトホルムアミド $0.167 \mathrm{~mol}$ とトリエチルアミン $0.83 \mathrm{~mol}$ を $-5^{\circ} \mathrm{C}$ で攪 拌下、オキシ塩化リン $0.183 \mathrm{~mol}$ 1,2ジメトキシエ

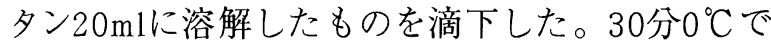
攪拌後加水分解し、さらに30分 $0^{\circ} \mathrm{C} て ゙$ 覺拌した。 得られたえ結晶をろ過し、氷水で洗浄し、温かい ベンゼンに溶解し有機層を分離し脱水し、活性炭 により脱色し、石油エーテルに加え攪拌した。得 られた結晶物をろ過し、真空乾燥した。

7)1-アザビシクロ $[3,4,0]$ ノナ-

$$
\text { 2,4-ジエン-6-オンの合成 }
$$

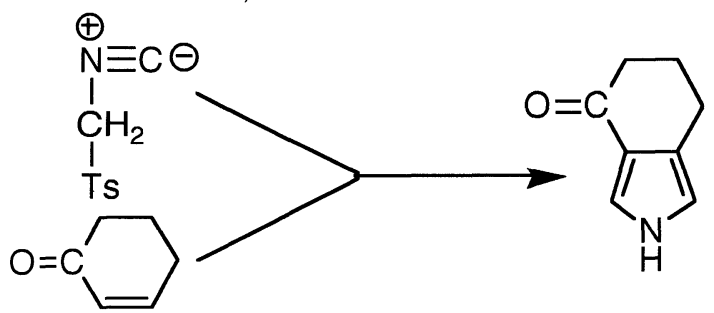

1,2-ジメトキシエタン $50 \mathrm{ml}$ に水素化ナトリウム $41.3 \mathrm{mmol}$ - $20^{\circ} \mathrm{C}$ で覺捧し、2シクロヘキセン-1オン $32.5 \mathrm{mmol}$ とPトシルメチルイソシアニド $32.5 \mathrm{mmol}$ 1,2ジメトキシエタン $50 \mathrm{ml}$ に溶解したものを滴下し た。1時間攪找し、室温まで戻し、加水分解後、 クロロホルムで抽出し飽和炭酸水素ナトリウム、 水で洗浄し脱水し、濃縮した。

\section{2 電解重合}

電解重合は作用極にインジウムースズ酸化物導 電硝子(ITO)、対極に白金板をそなえた一室構造の セル中、定電圧法にて行った。最適条件はピロー ルをモノマーとして印加電圧、重合時間、支持電 解質濃度をそれぞれ変化させたときの導電率変化 より設定した。

2.3 溶解試験

得られたポリマーを室温にて各種有機溶媒に対 して溶解するか試験した。

$3 \cdot$ 結果

得られたポリマーの溶解試験を行ったが一般的 な有機溶媒に対して不溶であった。ピロールモノ マーの電解重合に於ける最適条件は、溶媒アセ卜 ニトリル、支持電解質 $\mathrm{LiBF}_{4}$ モノマー濃度 $0.05(\mathrm{~mol} / \mathrm{l})$ に固定した場合、印加電圧 $4.0(\mathrm{~V})$ 、印 加時間60(分)、支持電解質濃度 $0.10(\mathrm{~mol} / \mathrm{l})$ の とき のホリマーが最も高い導電度を示した。得られた ポリマーの導電度をTable 1に示した。またモノ マーの同定はIR,GC-MS,CHN, ${ }^{1} \mathrm{H}-\mathrm{NMR}$ にて行った。

Table 1 Electrical conductivity of polymers

\begin{tabular}{cc}
\hline Polymer & Conductivity(S/cm) \\
\hline PPyrrole & $3.01 \times 10^{-2}$ \\
P3-AcPy & 測定不能 \\
P3-CpPy & $3.74 \times 10^{-7}$ \\
P3-CpnPy & $3.68 \times 10^{-7}$ \\
P3-DecPy & $1.48 \times 10^{-5}$ \\
\hline PPyrrole: ポリピロール \\
P3-AcPy : ポリ3-アセチルピロール \\
P3-CpPy : ポリ3-カプロイルピロール \\
P3-CpnPy : ポリ3-カプリノイルピロール \\
P3-DecPy : ポリ3-デシルピロール
\end{tabular}

以上の結果をまとめると、本研究段階では、ピ ロールの3位にアシル基、およびアルキル基の導 入に成功し、それを電解重合により重合したが、 電子吸引基であるアシル基の導入で、主鎖の $\pi$ 共 役に、大きな片寄りが生じたため、導電度の大幅 な低下が生じたものと考えられる。アシル基に、 直接ついたアルキル基の長さが極端に短い物以外 は、等しい導電度を示すことより、長さの長短は この場合には導電度に関係のないものであること がわかる。また、電子供与基で、溶解性の期待の もてる直鎖アルキル基の導入では、電子供与の影 響より、置換基による重合度の変化や、膜のモル ホロジーの影響が大きいため、導電度に若干の低 下が生じたものと考えられる。溶解性であるが、 一般的な有機溶媒に対して不溶になったが、これ は電解重合による架橋構造により高分子鎖間の相 互作用を弱めることができなかったものと考えら れる。溶解性をもたせるため、架橋構造の少ない 化学重合を行うか、3,4位置換体を合成し重合す ることで理論的に架橋構造のないポリマーを合成 する必要があると考えられる。

引用文献

1. Jürgen Rühe et al., Makromol. Chem., Rapid Commun. 10,103-108 (1989)

2. Hideyuki Masuda et al., J. Chem. Soc., Chem. Commun., 725 (1989) 